mice with murine cytomegalovirus and Pseudomonas aeruginosa, Staphylococcus aureus, or Candida albicans infections. Infect Immun 14:982-989

4. Kelsey DK, Olsen GA, Overall JC Jr, Glasgow LA 1977 Alteration of host defense mechanisms by MCMV. Infect Immun 18:754-760

5. Rinaldo CR Jr, Carney WP, Richter BS, Black PH, Hirsch MS 1980 Mechanisms of immunosuppression in cytomegalovirus mononucleosis. J Infect Dis 141:488-495

6. Selgrade MJ, Ahmed A, Sell KW, Gershwin ME, Steinberg AD 1976 Effect of $\mathrm{MCMV}$ on the in vitro responses of $\mathrm{T}$ and $\mathrm{B}$ cells to mitogens. $\mathrm{J}$ Immun 116:1459-1465

7. Osborn JE, Blazkovec AA, Walker DL 1968 Immunosuppression during acute murine cytomegalovirus infection. J Immunol 100:835-844

8. Chatterjee SN, Fiala M, Weiner J, Stewart JA, Stacey B, Warner N 1978 Primary cytomegalovirus and opportunistic infections: incidence in renal transplant recipients. JAMA 240:2446-2449

9. Rand KH, Pollard RB, Merigan TC 1978 Increased pulmonary superinfections in cardiac-transplant patients undergoing primary cytomegalovirus infection. N Engl J Med 298:951-953

10. Fische M, Soulillou JP, Bignon JD, Billavdel S, Guenel J 1984 T-lymphocyte monitoring in kidney transplant recipients undergoing cytomegalovirus infection or rejection episodes. Transplantation 37:421-423

11. Schooley RT, Hirsch MS, Colvin RB, Cosimi AB, Tolkoff-Rubin NE, McCluskey RT, Burton RC, Russell PS, Herrin JT, Delmonico FL, Giorgi JV, Henle W, Rubin RH 1983 Association of herpes virus infections with Tlymphocyte-subset alterations, glomerulopathy, and opportunistic infections after renal transplantation. N Engl J Med 308:307-313

12. Carney WP, Rubin RH, Hoffman RA, Hansen WP, Healey K, Hirsch MS 1978 Analysis of T-lymphocyte subsets in cytomegalovirus mononucleosis. J Immunol 126:2114-2116

13. Kelsey DK, Overall JC Jr, Glasgow LA 1978 Correlation of the suppression of mitogen responsiveness and the mixed lymphocyte reaction with the proliferative response to viral antigen of splenic lymphocytes from cytomegalovirus-infected mice. J Immunol 121:464-469

14. Boyum A 1974 Separation of blood leucocytes, granulocytes and lymphocytes. Tissue Antigens 4:269-274

15. Goldsmith JC, Moseley PL, Monick M, Brady M, Hunnighake GW 1983 Tlymphocyte subpopulation abnormalities in apparently healthy patients with hemophilia. Ann Intern Med 98:294-296

16. Cantor H, Shen FW, Boyse EA 1976 Separation of helper T cells from suppressor $T$ cells expressing different Ly components. J Exp Med 143:1391 1401

17. Carney WP, Hirsch MS 1981 Mechanisms of immunosuppression in cytomegalovirus mononucleosis. II. Virus-monocyte interactions. J Infect Dis 144:47-54

18. Rinaldo CR Jr, Ho M, Hamoudi WH, Gui X, DeBiasio RL 1983 Lymphocyte subsets and natural killer cell responses during cytomegalovirus mononucleosis. Infect Immun 40:472-477

19. Pass RF, Roper MA, August AM 1983 T-lymphocyte subpopulations in congenital cytomegalovirus infection. Infect Immun 41:1380-1382

20. Shannon K, Ball E, Wasserman RL, Murphy FK, Luby J, Buchanan GR 1983 Transfusion-associated cytomegalovirus infection and acquired immune deficiency syndrome in an infant. J Pediatr 103:859-863

21. Schooley RT, Hirsch MS, Colvin RB, Cosimi AB, Russell PS, Delmonico FL, Giorgi JV, Rubin RH 1983 Letter to the editor. N Engl J Med 309:111

22. Schroff RW, Gale RP, Fahey JL 1982 Regeneration of $T$ cell subpopulations after bone marrow transplantation: cytomegalovirus infection and lymphoid subset imbalance. J Immunol 129:1926-1930

23. Verdonck LF, DeGast GC 1984 Is cytomegalovirus infection a major cause of $\mathrm{T}$ cell alterations after (autologous) bone marrow transplantation? Lancet 1:932-935

\title{
Mode of Inhibitory Action of Bilirubin on Protein Kinase C
}

\author{
KIMIHIKO SANO, HAJIME NAKAMURA, AND TAMOTSU MATSUO \\ Department of Pediatrics, Kobe University School of Medicine, Kobe, Japan
}

\begin{abstract}
Ca}^{2+}$-activated, phospholipid-dependent protein kinase (protein kinase $C$ ) is widely distributed in mammalian tissues. Accumulating evidence has revealed that protein kinase $\mathrm{C}$ as well as cAMP-dependent protein kinase plays important roles in various cellular functions. The purpose of this study is to examine the effect of bilirubin on protein kinase $C$ and $\mathrm{CAMP}$-dependent protein kinase activity in a cell-free system as a cause of bilirubin toxicity to the central nervous system. Bilirubin inhibited protein kinase $C$ activity in a dose-dependent manner. This effect was markedly diminished by the addition of human serum albumin at a molar ratio of bilirubin to albumin of less than 1.0. Kinetic analysis revealed that bilirubin did not compete with phospholipid, diacylglycerol, or calcium. Bilirubin also inhibited cAMP-dependent protein kinase, but did not compete with cAMP. The inhibitory effect of bilirubin on protein kinase $C$ seems to be irreversible because removal of bilirubin by Sephadex G-25 column chromatography did not restore the protein kinase $C$ activ-
\end{abstract}

Received May 8, 1984; accepted February 13, 1985.

Correspondence to Dr. Kimihiko Sano, Department of Medicine, National Jewish Hospital and Research Center/National Asthma Center, 3800 East Colfax Avenue, Denver, CO 80206 ity. Observations reported herein suggest that bilirubin, especially in its free form, induces an irreversible change to the catalytically active site of protein kinase C. (Pediatr Res 19: 587-590, 1985)

\section{Abbreviation}

Protein kinase $\mathrm{C}$, calcium-activated, phospholipid-dependent protein kinase

Bilirubin is toxic to the central nervous system, causing encephalopathy, especially in low birth weight premature infants with hyperbilirubinemia and acidosis. The toxic mechanism of bilirubin has been extensively investigated. Several enzymes relating to oxidative phosphorylation and to metabolisms of carbohydrate, amino acid, and lipid are affected by bilirubin (for a review see Reference 1). However, no specific enzyme has been singled out as a target of bilirubin toxicity.

Recent evidence has revealed that protein phosphorylation is a very important pathway in various cellular functions including those of the nervous system (for a review see Reference 2). To 
date, there are four known types of protein kinases, namely, cAMP-dependent protein kinase, cGMP protein kinase, $\mathrm{Ca}^{2+}$ / calmodulin dependent protein kinases, and $\mathrm{Ca}^{2+}$-activated, phospholipid-dependent protein kinase (protein kinase C). Among these kinases, the role of protein kinase $C$ in various cellular functions has been extensively studied (for a review see Reference 3 ). In neuronal tissues, several proteins are reported to be substrates of protein kinase $\mathrm{C}$ including tyrosine hydroxylase, nicotinic acetylcholine receptor, microtubule-associated protein-2, myelin basic protein, GABA-modulin, Synapsin I, and $87 \mathrm{~K}$ protein (2). Recently Constantopoulos and Matsaniotis (4) reported that bilirubin inhibits cAMP-dependent protein kinase in vitro. The present study was designed to investigate the effect of bilirubin on protein kinase $\mathrm{C}$ in a cell free system as a possible cause of bilirubin toxicity to brain cells.

\section{EXPERIMENTAL PROCEDURES}

Materials and chemicals. A homogeneously purified protein kinase $C$ from rat brain was donated by Dr. Kikkawa, Department of Biochemistry, Kobe University School of Medicine (5). This homogeneous preparation of protein kinase $C$ was used in all experiments except that summarized in Table 1 in which we used protein kinase $C$ partially purified through DEAE-cellulose and Sephadex G 150 gel column chromatography as described by Kikkawa et al. (5). Calf thymus $\mathrm{Hl}$ histone was prepared by the method of Hashimoto et al. (6). Phospholipid mixture was extracted from bovine brain by the method of Folch et al. (7) and fractionated on a silicic acid column. Diolein was purchased from Nakarai Chemicals. $\left(\gamma^{-32} \mathrm{P}\right)$ ATP was prepared by the method of Glynn and Chappell (8). Bilirubin, human serum albumin, cAMP-dependent protein kinase from bovine heart were the products of Sigma. Prepacked sephadex G25 column (PD-10) was obtained from Pharmacia. Other chemicals were obtained from commercial sources.

Enzyme assay. Protein kinase $\mathrm{C}$ was assayed by measuring the incorporation of ${ }^{32} \mathrm{Pi}$ into $\mathrm{Hl}$ histone from $\left(\gamma-{ }^{32} \mathrm{P}\right)$ ATP. The standard reaction mixture $(0.25 \mathrm{ml})$ contained $5 \mu \mathrm{mol}$ of Tris/ $\mathrm{HCl}$ at $\mathrm{pH} 7.5,1.25 \mu \mathrm{mol}$ of magnesium chloride, $50 \mu \mathrm{g}$ of $\mathrm{Hl}$ histone, $2.5 \mathrm{nmol}$ of $\left(\gamma^{-32} \mathrm{P}\right)$ ATP $\left(1.0\right.$ to $\left.1.5 \times 10^{5} \mathrm{cpm} / \mathrm{nmol}\right)$, and $0.5 \mu \mathrm{g}$ of protein kinase C. Phospholipid, diolein, bilirubin, and $\mathrm{Ca}^{2+}$ were added as indicated in each experiment. cAMPdependent protein kinase was similarly assayed except that 50 $\mu \mathrm{g}$ of whole histone was used as substrate and cAMP was added instead of $\mathrm{Ca}^{2+}$, phospholipid, and diolein. Bilirubin was dissolved in $0.1 \mathrm{~N} \mathrm{NaOH}$ and then adjusted to $\mathrm{pH} 8.0$ with $0.2 \mathrm{~N}$ $\mathrm{HCl}$ in the dark. All reactions were carried out in plastic tubes. After incubation for $3 \mathrm{~min}$ at $30^{\circ} \mathrm{C}$, the reactions were stopped by the addition of $25 \%$ trichloroacetic acid. The acid-precipitable materials were collected on a Toyo-Roshi membrane filter (pore

Table 1. Irreversibility of inhibitory effect of bilirubin on protein kinase $C^{*}$

\begin{tabular}{lcc}
\hline & Before G25 & After G25 \\
Treatment & column chromatography & column chromatography \\
\hline \multicolumn{3}{c}{ pmol P/min } \\
Vehicle & $6150(100 \%)$ & $5870(100 \%)$ \\
Bilirubin & $1620(26 \%)$ & $1470(25 \%)$ \\
\hline
\end{tabular}

* Partially purified protein kinase $\mathrm{C}(100 \mu \mathrm{g})$ was preincubated with either $100 \mu \mathrm{M}$ of bilirubin or vehicle for $5 \mathrm{~min}$ at $4^{\circ} \mathrm{C}$, then subjected to $\mathrm{G} 25$ column (PD 10) and eluted with $20 \mathrm{mM}$ Tris/ $\mathrm{HCl}$ at $\mathrm{pH} 7.5$ containing $50 \mathrm{mM} 2$-mercaptoethanol and $0.5 \mathrm{mM}$ EGTA. An aliquot $(0.8 \mu \mathrm{g}$ protein) was subjected to protein kinase $\mathrm{C}$ assay before and after column chromatography as described in "Experimental procedures." The activity is expressed as total activity ( $\mathrm{pmol}{ }^{32} \mathrm{P}$ incorporated $/ \mathrm{min}$ ). The percentage activity is shown in parentheses where total activity of control is expressed as $100 \%$. The results represent the mean of triplicate samples of a single experiment. size, $0.45 \mu \mathrm{m})$. The radioactivity was determined using a Packard Tri-Carb liquid scintillation spectrometer, model 3320. Protein was determined by the method of Lowry et al. (9) with bovine serum albumin as a standard.

\section{RESULTS}

Protein kinase $\mathrm{C}$ requires $\mathrm{Ca}^{2+}$ and phospholipid for its activation. A small amount of unsaturated diacylglycerol such as diolein markedly increases the affinity of protein kinase $\mathrm{C}$ for $\mathrm{Ca}^{2+}$ and phospholipid $(10,11)$. Figure $1 A$ shows that bilirubininhibited protein kinase $\mathrm{C}$ in a dose-dependent manner when the enzyme was assayed in the presence of $\mathrm{Ca}^{2+}$, phospholipid, and diolein. Bilirubin also inhibited cAMP-dependent protein kinase in the presence of $1.0 \times 10^{-7} \mathrm{M}$ cAMP as shown in Figure $1 B$, which confirms previous report of Constantopoulos and Matsaniotis (4). The concentrations of bilirubin needed for half maximum inhibition of the enzymes were approximately $40 \mu \mathrm{M}$ for protein kinase $\mathrm{C}$ and $60 \mu \mathrm{M}$ for cAMP-dependent protein kinase.

Most of the bilirubin in the plasma is bound firmly to albumin (12). Only unbound bilirubin is thought to cross the blood-brain barrier where it could possibly impair damage brain function. Therefore, in the next experiments we added human serum albumin to the reaction mixture to test this concept in our cell free system. As shown in Figure 2, addition of albumin diminished inhibitory effect of bilirubin on protein kinase C. But it should be noted that bilirubin still significantly inhibited protein kinase $C$ in the presence of albumin when the bilirubin/albumin molar ratio was 2.0 . In the case of cAMP-dependent protein kinase, the effect of albumin could not be examined because cAMP bound to albumin and cAMP stimulated kinase activity could not be measured. But albumin did prevent the basal activity of cAMP-dependent protein kinase from inhibition by bilirubin (data not shown).

Several phospholipid-interacting drugs such as chlorpromazine, dibucaine, and tetracaine have been shown to inhibit pro-

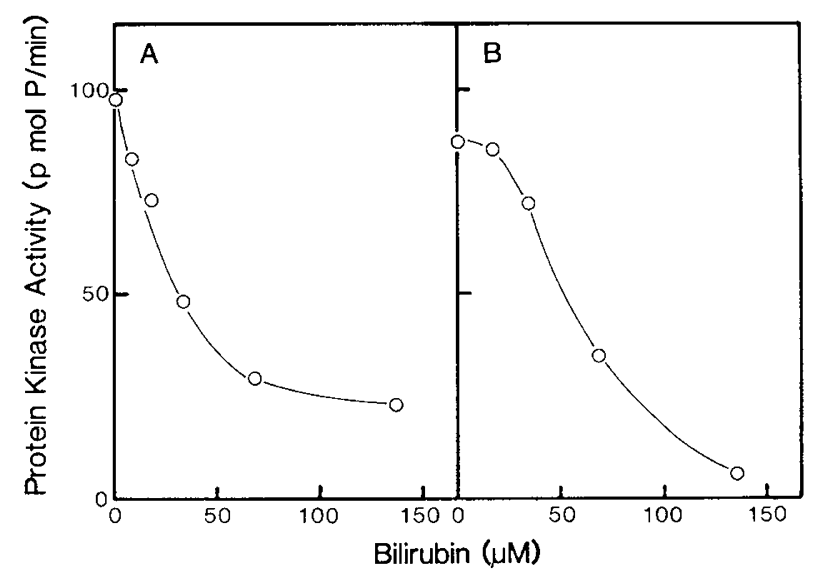

Fig. 1. Inhibition of protein kinase $C(A)$ and cAMP dependent protein kinase $(B)$ by bilirubin. $A$, protein kinase $C$ was assayed in the reaction mixture $(0.25 \mathrm{ml})$ which contained $5 \mu \mathrm{mol}$ of Tris $/ \mathrm{HCl}$ at $\mathrm{pH}$ $7.5,1.25 \mu \mathrm{mol}$ of magnesium chloride, $50 \mu \mathrm{mol}$ of calcium chloride, 50 $\mu \mathrm{g}$ of $\mathrm{Hl}$ histone, $2.5 \mathrm{nmol}$ of $\left(\gamma^{-32} \mathrm{P}\right)$ ATP $\left(1.5 \times 10^{5} \mathrm{cpm} / \mathrm{nmol}\right), 4 \mu \mathrm{g}$ of phospholipid, $0.5 \mu \mathrm{g}$ of diolein, $0.5 \mu \mathrm{g}$ of protein kinase $\mathrm{C}$, and various amounts of bilirubin as described in "Experimental procedures". The activity is expressed as pmol ${ }^{32} \mathrm{P}$ incorporated $/ \mathrm{min} /$ tube. Calcium-dependent basal activity is subtracted from each value. $B$, cAMP-dependent protein kinase was assayed in the reaction mixture $(0.25 \mathrm{ml})$ which contained $5 \mu \mathrm{mol}$ of Tris $/ \mathrm{HCl}$ at $\mathrm{pH} 7.5,1.25 \mu \mathrm{mol}$ of magnesium chloride, $50 \mu \mathrm{g}$ of whole histone, $2.5 \mathrm{nmol}$ of $\left(\gamma-{ }^{32} \mathrm{P}\right)$ ATP $\left(1.5 \times 10^{5}\right.$ $\mathrm{cpm} / \mathrm{nmol}), 25 \mathrm{pmol}$ of cAMP, $10 \mu \mathrm{g}$ of cAMP-dependent protein kinase, and various amounts of bilirubin as described in "Experimental procedures". The results represent three different experiments. 
tein kinase $C$ activity by competing with phospholipid (13). It has been reported that bilirubin binds reversibly to phospholipids of mitochondria, intact cells, and cell fragments (14). Therefore, we examined whether or not bilirubin inhibits protein kinase $C$ through interaction with phospholipids. Unlike cationic amphiphylic drugs, the inhibitory effect of bilirubin was not abolished by increasing the amount of phospholipid as shown in Figure 3. Moreover, increasing the amount of diolein or $\mathrm{Ca}^{2+}$ in the

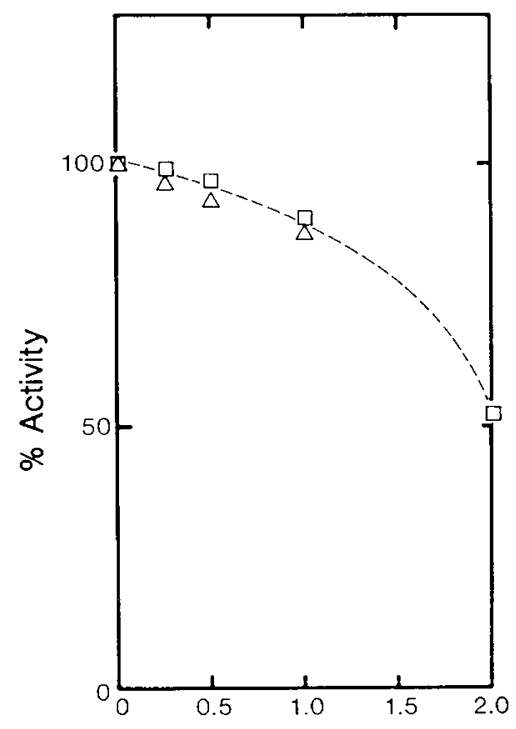

Bilirubin/Albumin Molar Ratio

Fig. 2. Effect of the molar ratio of bilirubin to albumin on the inhibitory action of bilirubin on protein kinase $C$. Protein kinase $C$ was assayed under conditions similar to those specified in the legend to Figure 1 except that various amounts of human serum albumin and bilirubin were added as indicated. The concentration of albumin was fixed, and that of bilirubin was varied. Protein kinase activity without bilirubin is expressed as $100 \%$. $\Delta$, with $4.7 \mathrm{mg} / \mathrm{ml}$ of albumin; albumin; $\square$, with 9.4 $\mathrm{mg} / \mathrm{ml}$ of albumin. The results represent three different experiments.

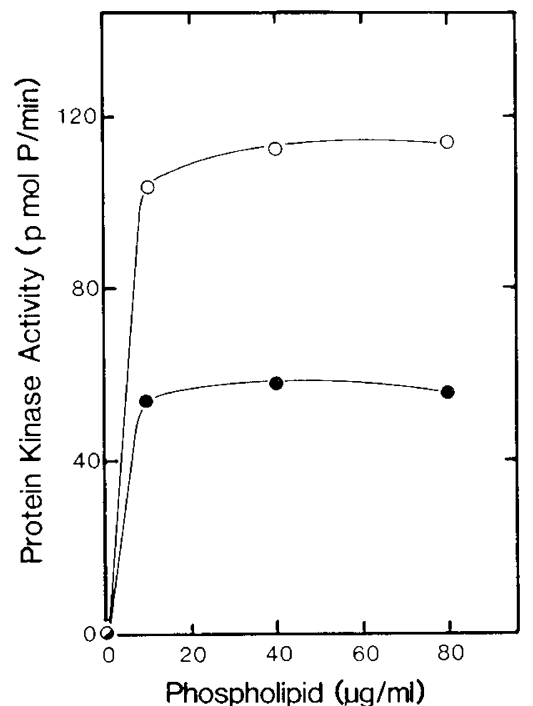

Fig. 3. Effect of phospholipid concentration on the inhibitory action of bilirubin on protein kinase $C$. Protein kinase $C$ was assayed under conditions similar to those specified in the legend to Figure 1 except that various concentrations of phospholipid were added as indicated. Calcium-dependent basal activity is subtracted from each value. $\mathrm{O}_{-} \mathrm{O}$, without bilirubin; representative for two different experiments.

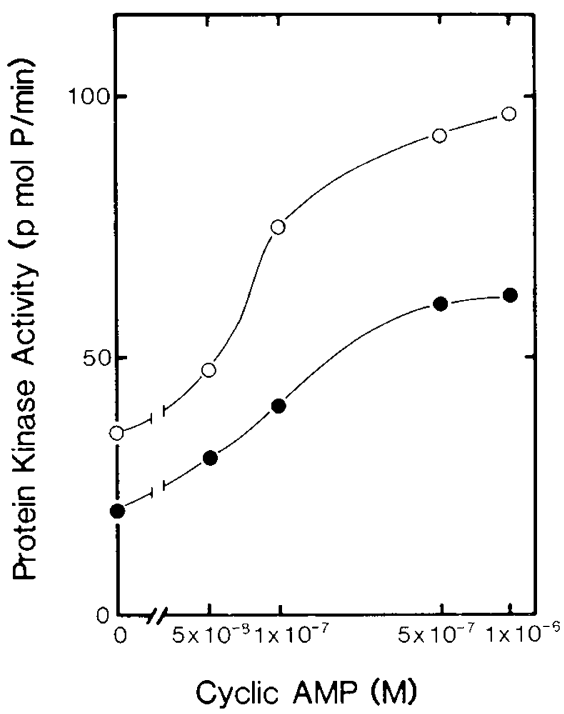

Fig. 4. Effect of CAMP concentration on the inhibitory action of bilirubin on cAMP-dependent protein kinase. cAMP-dependent protein kinase was assayed under conditions similar to those specified in the legend to Figure 1 except that various concentrations of cAMP were added as indicated. $\bigcirc-O$, without bilirubin; $\bullet-$, with bilirubin $(68 \mu \mathrm{M})$. The results represent two different experiments.

reaction mixture did not affect inhibitory action of bilirubin (data not shown). Increasing the amount of cAMP also failed to prevent cAMP-dependent protein kinase activity from inhibition by bilirubin as shown in Figure 4 . Therefore, bilirubin seems to inhibit both protein kinase $\mathrm{C}$ and cAMP-dependent protein kinase through interaction with catalytically active sites rather than through competition with their activators.

The inhibitory effect of bilirubin on protein kinase $C$ seems to be irreversible as shown in Table 1 . Once protein kinase $C$ was preexposed to $100 \mu \mathrm{M}$ of bilirubin, the activity of protein kinase $\mathrm{C}$ significantly decreased despite a reduction in the final concentration of bilirubin in the reaction mixture to $8 \mu \mathrm{M}$. Furthermore, the activity of protein kinase $\mathrm{C}$ was not restored by removal of bilirubin by Sephadex G25 gel column chromatography.

\section{DISCUSSION}

The activation process of protein kinase $\mathrm{C}$ is tightly coupled to phosphatidylinositol turnover $(3,11)$ which is provoked by a wide variety of extracellular messengers including neurotransmitters and many biologically active substances (15). Protein phosphorylation is presumed to be a final common pathway of signal transduction, and actually several substrates of protein kinase $C$ in nervous tissue have been reported (2).

Our present results demonstrate that bilirubin inhibits both protein kinase $\mathrm{C}$ and cAMP-dependent protein kinase in a cellfree system. Protein kinase $C$ activity was not totally inhibited even when high concentration of bilirubin was added as shown in Figure $1 A$. The exact reason of this is unclear at present, but when protein kinase $C$ was preincubated with bilirubin in the absence of lipids, bilirubin totally inhibited protein kinase $C$ at $200 \mu \mathrm{M}$ (data not shown). This result suggests that lipids might somehow protect protein kinase $\mathrm{C}$ as reported in the case of $\mathrm{Ca}^{2+}$-dependent inactivation of this enzyme (5).

The binding activity of bilirubin to phospholipid is considered to be a cause of bilirubin toxicity $(14,16)$; however, our results suggest that bilirubin inhibits protein kinase $C$ through interacting with its catalytically active site(s) rather than competing with phospholipids. The results shown in Table 1 suggest that bilirubin might cause covalent modification or conformational change on the catalytic site(s) of protein kinase $\mathrm{C}$.

Whether or not the inhibitory action of bilirubin on protein 
kinase $C$ in vitro is directly related to the state of kernicterus remains unclear from our present results. We failed to demonstrate an in vivo effect of bilirubin on the specific activity of protein kinase $C$ in adult Sprague-Dawley rats (data not shown). However, kernicterus is confined to the very early neonatal period or low birth weight infants; acidosis or hypoalbuminemia also tend to occur in such patients. Acidosis or hypoalbuminemia increases unbound bilirubin levels allowing the accumulation of bilirubin in central nervous tissues (17). Therefore, experiments using premature or very early neonatal animals with hyperbilirubinemia are necessary in order to clarify precisely the role of protein kinases in kernicterus.

\section{REFERENCES}

1. Karp WB 1979 Biochemical alterations in neonatal hyperbilirubinemia and bilirubin encephalopathy. Pediatrics 64:361-368

2. Nestler EJ, Greengard $P 1983$ Protein phosphorylation in the brain. Nature 305:583-588

3. Nishizuka Y 1984 The role of protein kinase $C$ in cell surface signal transduction and tumor promotion. Nature 308:693-698.

4. Constantopoulos A, Matsaniotis N 1976 Bilirubin inhibition of protein kinase: its prevention by cyclic AMP. Cytobios 17:17-20

5. Kikkawa U, Takai Y, Minakuchi R, Inohara S, Nishizuka Y 1982 Calciumactivated, phospholipid-dependent protein kinase from rat brain. J Biol Chem 257:13341-13348

6. Hashimoto E, Takeda M, Nishizuka Y, Hamana K, Iwai K 1976 Studies on the sites in histones phosphorylated by adenosine $3^{\prime}: 5^{\prime}$-monophosphate- dependent and guanosine $3^{\prime}: 5^{\prime}$-monophosphate-dependent protein kinase. J Biol Chem 251:6287-6293

7. Folch J, Lees M, Stanley GHS 1957 A simple method for the isolation and purification of total lipides from animal tissues. J Biol Chem 226:497-509

8. Glynn IM, Chappell JB 1964 A simple method for the preparation of ${ }^{32} \mathrm{P}-$ labeled adenosine triphosphate of high specific activty. Biochem J 90:147149

9. Lowry OH, Rosebrough NJ, Farr AL, Randall RJ 1951 Protein measurement with the folin phenol reagent. J Biol Chem 193:265-275

10. Takai Y, Kishimoto A, Kikkawa U, Mori T, Nishizuka Y 1979 Unsaturated diacylglycerol as a possible messenger for the activation of calcium-activated, phospholipid-dependent protein kinase system. Biochem Biophys Res Commun 91:1218-1224

11. Kishimoto A, Takai Y, Mori $T$, Kikkawa U, Nishizuka Y 1980 Activation of calcium and phospholipid-dependent protein kinase by diacylglycerol, its possible relation to phosphatidylinositol turnover. J Biol Chem 255:22732276

12. Ostrow JD, Schmid R 1963 The protein-binding of $\mathrm{C}^{14}$-bilirubin in human and murine serum. J Clin Invest 42:1286-1299

13. Mori T, Takai Y, Minakuchi R, Yu B, Nishizuka Y 1980 Inhibitory action of chlorpromazine, dibucaine, and other phospholipid-interacting drugs on calcium-activated, phospholipid-dependent protein kinase. J Biol Chem 255:8378-8380

14. Mustafa MG, King TE 1970 Binding of bilirubin with lipid. J Biol Chem 245:1084-1089

15. Michell RH 1975 Inositol phospholipids and cell surface receptor function. Biochim Biophys Acta 415:81-147

16. Eriksen EF, Danielsen H, Brodersen R 1981 Bilirubin-liposome interaction. J Biol Chem 256:4269-4274

17. Diamond I, Schmid R 1966 Experimental bilirubin encephalopathy. The mode of entering of bilirubin $-{ }^{-14} \mathrm{C}$ into the central nervous system. J Clin Invest 45:678-689

\title{
Unsuccessful Attempts to Induce Peroxisomes in Two Cases of Zellweger Disease by Treatment with Clofibrate
}

\author{
INGEMAR BJÖRKHEM, SVANTE BLOMSTRAND, HANS GLAUMANN, AND \\ BIRGITTA STRANDVIK \\ Department of Clinical Chemistry at the Karolinska Institute, Huddinge Hospital, Huddinge, Department of \\ Pediatrics, Borås Hospital, Borås, Departments of Pathology and Pediatrics at the Karolinska Institute, \\ Huddinge Hospital, Huddinge, Sweden
}

\begin{abstract}
The cerebro-hepato-renal syndrome of Zellweger is a fatal hereditary disease and most of the affected infants die before the age of 6 months. Most probably the fatal outcome of the disease is due to an apparent complete lack of peroxisomes in the liver, kidneys, and brain. Treatment with clofibrate is known to increase drastically the number of peroxisomes in mammalian liver. We therefore treated two infants with the Zellweger syndrome with clofibrate ( 30 and $45 \mathrm{mg} / \mathrm{kg}$ body weight, respectively) for 3-4 wk. No clinical effect of the treatment was observed in any of the two cases, and the pattern of abnormal bile acids in serum did not change. No peroxisomes could be
\end{abstract}

Received October 22, 1984; accepted February 4, 1985

Requests for reprints should be addressed to Dr. Ingemar Björkhem, Department of Clinical Chemistry I, Huddinge Hospital, S-141 86 Huddinge, Sweden.

Supported by the Swedish Medical Research Council Projects 3141, 3492, and 5361 . detected by electron microscopy of liver biopsies taken immediately after the treatment. Our failure to induce peroxisomes in the two Zellweger patients is in accord with the hypothesis that the protein missing in this autosomal recessive disease is absolutely essential for the formation of peroxisomes. (Pediatr Res 19: 590-593, 1985)

The Zellweger syndrome is a fatal hereditary disease characterized by craniofacial malformations, hypotonus, liver enlargement, renal cysts, central nervous disturbances, and mental retardation (1). In general affected infants die before 6 months of age. The most characteristic histological finding in this disease is an apparently complete absence of peroxisomes in the liver and kidneys (2). Goldfischer et al. (2) have also demonstrated 